Arab Univ. J. Agric. Sci., Ain Shams Univ., Cairo, 13(2), 471-480, 2005

\title{
IMPROVING CANINO APRICOT TREES PRODUETIVITY BY FOLIAR SPRAY WITH BORON, GA 3 AND ACTIVE DRY YEAST [30]
}

\author{
Hassan $^{1}$, H.S.A.; E.A.M. Mostafa ${ }^{1}$ and Dorria M. Ahmed ${ }^{1}$
}

\begin{abstract}
The present investigation was carried out during two successive seasons of 2002 and 2003 on Canino Apricot trees budded on seedlings rootstock at a private orchard located at El-Khatatba district, Menofia Governorate Egypt. Trees were sprayed at full-bloom stage with boron, $\mathrm{GA}_{3}$ and active dry yeast at different concentration alone or in their combinations. Results showed that spraying Boron, $\mathrm{GA}_{3}$ and active dry yeast either singly or in combination caused a remarked promotion in leaf mineral status, yield and fruit quality compared with control treatment Combined application solution of $400 \mathrm{ppm}$ Boric acid, $40 \mathrm{ppm} \mathrm{GA}_{3}$ and $2 \%$ active dry yeast at full bloom stage gave the best results with regard to the yield and fruit quality of Canino Apricot.
\end{abstract}

Key words: Boric acid, Gibberellic acid, Active dry yeast, Apricot cv. Canino, Fruit quality, Leaf mineral content.

\section{INTRODUCTION}

The name "Apricot" Comes from the Latin word "Praecoqum" which means early ripe. It is a number of the plum family (Rosacae) and has the botanical name "Prunus armeniaca L." it was mentioned that apricot was known in China three thousand year before Christ.

Total cultivated area reached about 20091 feddans the fruiting area is about 14800 feddans producing about 103070 tons according to Statistics of the Ministry of Agriculture in 2003.

Boron is an essential trace element required for optimal growth and development of higher plants. Boron is important in pollen germination and pollen tube growth resulting in successful fruit setting (Stanle and Lichtenberg, 1963).

Boron fertilizer increased B concentrations in flowers, promoted pollen germination, reduced the percentage of fall of flowers and fruits of apricots, increased the percentage of fertile fruits and thus increased yield. Therefore, B fertilizers may increased yield, particular when plant are grown on sandy soil with a low content of valiable $\mathrm{B}$ as shown by Yogaratnam \& Johnson 1982 and Nyomova \& Brown 1997.

Many investigators studied the role of $\mathrm{GA}_{3}$ on fruit set and yield of pear trees and found a stimulating effect on number

1- Pomology Department, National Research Centre, El-Behoos St., Dokki, Cairo, Egypt 
of fruits/tree and final yield (Wertheim et al 1973; Antognozzi \& Jackson 1975; Embleton et al 1973; Agusti et al 1982; Abou Raya et al 2000 and Mostafa et al 2001) on pear trees.

The various positive effect of active dry yeast were attributed to its content of different nutrients, higher percentage of proteins, Large amount of vitamin B and natural growth hormones namly, cytokinins. Also application of active dry yeast is very effective in releasing $\mathrm{CO}_{2}$ (Ferguson et al 1987) which improves net photosynthesis (Ferguson et al 1987; Idso et al 1995; Hegab et al 1997; Mansour 1998; Attala et al 2000 and Eman et al 2002).

The present investigation was therefore undertaken to study the influence of spraying Boron, $\mathrm{CA}_{3}$ and active dry yeast alone or in combination on leaf mineral status, yield and fruit quality of Canino Apricot trees grown under sandy soil.

\section{MATERIAL AND METHODS}

The present investigation was carried out during two successive seasons of 2002 and 2003 on Canino apricot trees budded on seedlings rootstock, at a private orchard located at EL-Khatatba district, Minufiya Governorate Egypt.

Trees were about 8 years old planted at $5 \times 6$ meter apart in sandy soil. The selected trees were disease free, uniform in shape and size, the trees were under drip irrigation system and received the normal cultural practices usually applied in commercial orchard.

A completely randomized block design was used where the following treatments were involved:
1- Control (untreated trees).

2- Spraying boric acid solution at 200 ppm.

3- Spraying boric acid solution at 400 ppm.

4- Spraying $\mathrm{GA}_{3}$ solution at $20 \mathrm{ppm}$.

5- Spraying $\mathrm{GA}_{3}$ solution at 40 ppm.

6- Spraying Active dry yeast solution at $1 \%$.

7- Spraying Active dry yeast solution at $2 \%$.

8- Spraying solution of Boric acid at $200 \mathrm{ppm}+\mathrm{GA}_{3} 20 \mathrm{ppm}+\mathrm{ac}-$ tive dry yeast at $1 \%$.

9- Spraying solution Boric acid at $400 \mathrm{ppm}+\mathrm{GA}_{3} 40 \mathrm{ppm}+$ active dry yeast at $2 \%$.

Dry yeast was activated by dissolving the definite amount in worm water $\left(38^{\circ} \mathrm{C}\right)$, adding sugar at the same rate and kept over night for nearly 12 hours before spraying.

Dry yeast contained $34.85 \%$ protein, $7.55 \%$ ash, $6.54 \%$ glycogen, $2.9 \%$ fats and $4.92 \%$ cellulose.

All treatments were replicated three times where one tree per each treatment was sprayed at full bloom in each season with solution till run off.

Triton $\mathrm{B}$ as a wetting agent at $0.1 \%$ concentration was added to all the spraying solutions as well as tap water in the control. During both seasons data were recorded for the following parameters:

\section{1- Leaf mineral status}

In early June of each season samples of twenty leaves from middle part of shoot (according to Chuntanaparb and Cummings (1981) were selected at random from each replicate, weighed 
grounded and finally digested to determine the percentage of $\mathrm{N}, \mathrm{P}$ and $\mathrm{K}$ according to Wilde et al 1985. Determination was carried out on dry weight basis.

\section{2- Yield}

The yield expressed as weight of fruit/ tree attained the harvest stage at the end of May was determined in both seasons.

\section{3- Fruit physical and chemical charac- teristics}

\subsection{Fruit physical characteristics}

Sample of 20 mature fruits were taken from each replicate tree of each treatment and the following characteristics were determined:

1. Average fruit weight (gm).

2. Average fruit volume $\left(\mathrm{cm}^{3}\right)$.

3. Specific grafity $\left(\mathrm{gm} / \mathrm{cm}^{3}\right)$.

4. Average fruit length and diameter (cm).

5. Fruit shape index (L/D).

6. Fruit firmness was determined as Lb/inch ${ }^{2}$ by using a Magness Taylor pressure tester 5/16 inch. Plunger.

\subsection{Fruit chemical characteristics}

1. Total soluble solids of fruit Juice (TSS\%) was measured by using a hand refractometer (A.O.A.C 1985) .

2. Fruit acidity the percentage of total acidity in fruit juice was determined as malic acid according to (A.O.A.C 1985).

3. Total soluble solids / acid ratio: was calculated.

\section{Statistical analysis}

The obtained data were subjected to analyses of variance and Duncan multiple range test used to differentiate means (Duncan, 1955).

\section{RESULTS AND DISCUSSION}

\section{1- Leaf $N, P$ and $K$ contents}

It is evident from the data in Table (1)that single or combined application of 200 or $400 \mathrm{ppm}$ boric acid, 20 or $40 \mathrm{ppm}$ $\mathrm{GA}_{3}$ and 1 or $2 \%$ active dry yeast, significantly improved leaf Nitrogen percentage compared with the control in both seasons.

The promotion occurred was coincided with the increase in the concentrations of the three studied materials. Combined applications of the three investigated materials were preferable than single application of each. The highest $\mathrm{N}$ percentage were obtained with spraying boric acid at $400 \mathrm{ppm}+\mathrm{GA}_{3}$ at $40 \mathrm{ppm}+2 \%$ active dry yeast in the two seasons.

Concerning phosphorus percentage in leaves; results in Table (1) revealed that different treatments tended to increase $\mathrm{P}$ content in the leaves as compared with control. The increment in phosphorus\% developed insignificant between treatments in both seasons.

As for potassium\% in leaves, results in Table (1) cleared that it was significantly affected by different treatments as compared with the control. The highest $\mathrm{K} \%$ in leaves were recorded by spraying trees with boric acid at $200 \mathrm{ppm}+\mathrm{GA}_{3}$ at $20 \mathrm{ppm}+1 \%$ active dry yeast in both seasons. 
Table 1. Effect of foliar spraying with Boric acid, $\mathrm{GA}_{3}$ and active dry yeast on leaf mineral status of Canino Apricot trees during 2002 and 2003 seasons.

\begin{tabular}{|c|c|c|c|c|c|c|}
\hline \multirow{2}{*}{ Treatments } & \multicolumn{2}{|c|}{$\mathrm{N} \%$} & \multicolumn{2}{|c|}{$\mathrm{P} \%$} & \multicolumn{2}{|c|}{$\mathrm{K} \%$} \\
\hline & 2002 & 2003 & 2002 & 2003 & 2002 & 2003 \\
\hline Control & $1.96^{\mathrm{c}}$ & $1.93^{\mathrm{d}}$ & 0.17 & 0.18 & $2.30^{\mathrm{g}}$ & $2.33^{\mathrm{e}}$ \\
\hline Boric acid at $200 \mathrm{ppm}$ & $2.60^{\mathrm{b}}$ & $2.63^{\mathrm{c}}$ & 0.19 & 0.20 & $2.46^{\mathrm{f}}$ & $2.43^{\mathrm{de}}$ \\
\hline Boric acid at $400 \mathrm{ppm}$ & $2.66^{\mathrm{b}}$ & $2.73^{\mathrm{bc}}$ & 0.20 & 0.20 & $2.56^{\mathrm{ef}}$ & $2.63^{\mathrm{cd}}$ \\
\hline $\mathrm{GA}_{3}$ at $20 \mathrm{ppm}$ & $2.83^{\mathrm{ab}}$ & $2.86^{\mathrm{abc}}$ & 0.20 & 0.20 & $2.66^{\mathrm{de}}$ & $2.73^{\mathrm{c}}$ \\
\hline $\mathrm{GA}_{3}$ at $40 \mathrm{ppm}$ & $2.93^{\mathrm{a}}$ & $2.96^{\mathrm{ab}}$ & 0.21 & 0.21 & $2.76^{\mathrm{cd}}$ & $2.76^{\mathrm{bc}}$ \\
\hline Active dry yeast $1 \%$ & $2.76 \mathrm{ab}$ & $2.96 a b$ & 0.22 & 0.22 & $2.90 \mathrm{ab}$ & $2.83 \mathrm{abc}$ \\
\hline Active dry yeast $2 \%$ & $2.76^{\mathrm{ab}}$ & $2.96^{\mathrm{ab}}$ & 0.22 & 0.22 & $2.90^{\mathrm{ab}}$ & $2.83^{\mathrm{abc}}$ \\
\hline $\begin{array}{l}\text { Boric acid } 200 \mathrm{ppm}+ \\
\mathrm{GA}_{3} 20 \mathrm{ppm}+\text { yeast } 1 \%\end{array}$ & $2.93^{\mathrm{a}}$ & $3.03^{\mathrm{a}}$ & 0.23 & 0.23 & $3.00^{\mathrm{a}}$ & $3.03^{\mathrm{a}}$ \\
\hline $\begin{array}{l}\text { Boric acid } 400 \mathrm{ppm}+ \\
\mathrm{GA}_{3} 40 \mathrm{ppm}+\text { yeast } 2 \%\end{array}$ & $2.96^{\mathrm{a}}$ & $3.06^{\mathrm{a}}$ & 023 & 0.23 & $2.96^{\mathrm{ab}}$ & $3.00^{\mathrm{ab}}$ \\
\hline
\end{tabular}

Means having the same letters (s) in each column are insignificantly differ at a level of 5\%

\section{2- Yield}

Data presented in Table (2) cleared that yield as weight $(\mathrm{kg})$ of fruits per tree was significantly affected by different treatments than that of control in the two seasons. The highest yield were recorded from trees sprayed with Boric acid at 400 $\mathrm{ppm}+\mathrm{GA}_{3}$ at $40 \mathrm{ppm}+$ active dry yeast at $2 \%$ in both seasons. Meanwhile, the lowest yield was recorded from the control treatment trees.

\section{3- Fruit physical and chemical charac- teristics}

\section{3-1- Fruit characteristics}

It is evident from the data given in Table (2) that fruit weight and volume were significantly increased by different treatments as compared with the control trees, during both seasons of such study. The heaviest and largest fruit was obtained by spraying boric acid at $400 \mathrm{ppm}$ $+\mathrm{GA}_{3}$ at $20 \mathrm{ppm}+$ active dry yeast at $2 \%$ 
Table 2. Effect of foliar spraying with Boric acid, $\mathrm{GA}_{3}$ and active dry yeast on yield, fruit weight, fruit volume and specific grafity of Canino Aprioct trees during 2002 and 2003 seasons.

\begin{tabular}{|c|c|c|c|c|c|c|c|c|}
\hline \multirow[t]{2}{*}{ Treatments } & \multicolumn{2}{|c|}{ Yield kg/tree } & \multicolumn{2}{|c|}{ Fruit weight } & \multicolumn{2}{|c|}{ Fruit volume $\left(\mathrm{cm}^{3}\right)$} & \multicolumn{2}{|c|}{$\begin{array}{l}\text { Specific } \\
\text { grafity }\end{array}$} \\
\hline & 2002 & 2003 & 2002 & 2003 & 2002 & 2003 & 2002 & 2003 \\
\hline Control & $23.45^{\mathrm{f}}$ & $22.80^{\mathrm{c}}$ & $26.89^{d}$ & $25.10^{\mathrm{c}}$ & $26.87^{\mathrm{e}}$ & $24.83^{\mathrm{d}}$ & 0.99 & 1.00 \\
\hline Boric acid at $200 \mathrm{ppm}$ & $29.01^{\mathrm{cd}}$ & $26.91^{\mathrm{b}}$ & $30.27^{\mathrm{c}}$ & $29.71^{b}$ & $29.44^{\mathrm{de}}$ & $27.50^{\mathrm{cd}}$ & 1.02 & 1.07 \\
\hline Boric acid at $400 \mathrm{ppm}$ & $30.84^{\mathrm{ab}}$ & $29.02^{\mathrm{a}}$ & $29.39^{\mathrm{cd}}$ & $32.29^{\mathrm{b}}$ & $30.55^{\mathrm{cd}}$ & $31.67^{b c}$ & 0.96 & 1.02 \\
\hline $\mathrm{GA}_{3}$ at $20 \mathrm{ppm}$ & $27.77^{\mathrm{de}}$ & $26.40^{\mathrm{b}}$ & $29.53 \mathrm{~cd}$ & $32.47^{\mathrm{b}}$ & $28.89^{\mathrm{de}}$ & $32.50 b^{c}$ & 1.01 & 0.99 \\
\hline $\mathrm{GA}_{3}$ at $40 \mathrm{ppm}$ & $29.43^{\mathrm{bc}}$ & $28.92^{\mathrm{a}}$ & $33.55^{\mathrm{ab}}$ & $38.97^{\mathrm{a}}$ & $33.60^{\mathrm{b}}$ & $39.17^{\mathrm{a}}$ & 1.02 & 1.03 \\
\hline Active dry yeast $1 \%$ & $27.30^{\mathrm{e}}$ & $26.14^{\mathrm{b}}$ & $31.57^{\mathrm{bc}}$ & $32.88^{\mathrm{b}}$ & $31.53^{\text {bcd }}$ & $32.50 \mathrm{bc}$ & 0.99 & 1.20 \\
\hline Active dry yeast $2 \%$ & $29.09^{\mathrm{cd}}$ & $28.59^{\mathrm{a}}$ & $32.00^{\mathrm{bc}}$ & $31.60^{\mathrm{b}}$ & $33.20^{\mathrm{bc}}$ & $32.50 b^{c}$ & 0.96 & 0.97 \\
\hline $\begin{array}{l}\text { Boric acid } 200 \mathrm{ppm}+\mathrm{GA}_{3} \\
20 \mathrm{ppm}+\text { yeast } 1 \%\end{array}$ & $30.18^{\mathrm{abc}}$ & $29.11^{\mathrm{a}}$ & $32.47^{\mathrm{bc}}$ & $33.02^{\mathrm{b}}$ & $32.27^{\mathrm{bc}}$ & $33.33^{\mathrm{b}}$ & 1.00 & 0.98 \\
\hline $\begin{array}{l}\text { Boric acid } 400 \mathrm{ppm}+\mathrm{GA}_{3} \\
40 \mathrm{ppm}+\text { yeast } 2 \%\end{array}$ & $30.98^{\mathrm{a}}$ & $29.27^{\mathrm{a}}$ & $35.73^{\mathrm{a}}$ & $38.20^{\mathrm{a}}$ & $36.33^{\mathrm{a}}$ & $42.00^{\mathrm{a}}$ & 0.98 & 0.89 \\
\hline
\end{tabular}

Means having the same letters (s) in each column are insignificantly differ at a level of 5\%

in both seasons. The values were (35.73, there was no constant trend due to differ$38.2 \mathrm{gm})$ for fruit weight and $(36.33,42.0$ ent treatment in the two seasons.

$\mathrm{cm}^{3}$ ) for fruit volume in the first and second seasons, respectively. On the other hand control treatment gave the lowest fruit weight and volume since they were $(26.89,25.1 \mathrm{gm})$ and $\left(26.87-24.83 \mathrm{~cm}^{3}\right)$ in both seasons, respectively.

Specific grafity was not affected significantly by different treatments and

\section{3- Fruit dimension, shape index and firmness}

Data in Table (3) revealed that, fruit length was not affected significantly by different treatments in the first season. Meanwhile, in the second one treatments 
Table 3. Effect of foliar spraying with Boric acid, $\mathrm{GA}_{3}$ and active dry yeast on fruit length, fruit width, fruit shape index and fruit firmness on Canino Apricot trees during 2002 and 2003 seasons.

\begin{tabular}{|c|c|c|c|c|c|c|c|c|}
\hline \multirow{2}{*}{ Treatments } & \multicolumn{2}{|c|}{ Fruit length $(\mathrm{cm})$} & \multicolumn{2}{|c|}{ Fruit width $(\mathrm{cm})$} & \multicolumn{2}{|c|}{$\begin{array}{l}\text { Fruit shape } \\
\text { index }\end{array}$} & \multicolumn{2}{|c|}{$\begin{array}{l}\text { Fruit firmness } \\
\quad \mathrm{Lb} / \mathrm{inch}^{2}\end{array}$} \\
\hline & 2002 & 2003 & 2002 & 2003 & 2002 & 2003 & 2002 & 2003 \\
\hline Control & 3.67 & $3.35^{\mathrm{c}}$ & $3.60^{\mathrm{c}}$ & $3.33^{c}$ & 1.01 & 1.00 & $12.17^{\mathrm{c}}$ & $13.17^{\mathrm{c}}$ \\
\hline Boric acid at $200 \mathrm{ppm}$ & 3.77 & $3.70^{\mathrm{abc}}$ & $3.78^{\mathrm{b}}$ & $3.58^{\mathrm{b}}$ & 0.99 & 1.03 & $14.67^{\mathrm{b}}$ & $15.50^{\mathrm{a}}$ \\
\hline Boric acid at $400 \mathrm{ppm}$ & 3.77 & $3.67^{\mathrm{abc}}$ & $3.82^{\mathrm{ab}}$ & $3.65^{\mathrm{ab}}$ & 0.98 & 1.00 & $15.83^{\mathrm{a}}$ & $16.03^{\mathrm{a}}$ \\
\hline $\mathrm{GA}_{3}$ at $20 \mathrm{ppm}$ & 3.77 & $3.65^{\mathrm{abc}}$ & $3.77^{\mathrm{bc}}$ & $3.67^{\mathrm{ab}}$ & 0.99 & 0.99 & $15.77^{\mathrm{a}}$ & $15.87^{\mathrm{a}}$ \\
\hline $\mathrm{GA}_{3}$ at $40 \mathrm{ppm}$ & 3.83 & $4.00^{\mathrm{a}}$ & $3.94^{\mathrm{a}}$ & $3.86^{\mathrm{a}}$ & 0.96 & 1.03 & $15.53^{\mathrm{a}}$ & $15.90^{\mathrm{a}}$ \\
\hline Active dry yeast $1 \%$ & 3.69 & $3.58^{\mathrm{bc}}$ & $3.667^{\mathrm{bc}}$ & $3.70^{\mathrm{ab}}$ & 1.00 & 0.96 & $14.67^{\mathrm{b}}$ & $14.83^{\mathrm{b}}$ \\
\hline Active dry yeast $2 \%$ & 3.82 & $3.52^{\mathrm{bc}}$ & $3.66^{\mathrm{bc}}$ & $3.51^{\mathrm{bc}}$ & 1.04 & 0.99 & $14.60 \mathrm{~b}$ & $14.63^{\mathrm{b}}$ \\
\hline $\begin{array}{l}\text { Boric acid } 200 \mathrm{ppm}+\mathrm{GA}_{3} \\
20 \mathrm{ppm}+\text { yeast } 1 \%\end{array}$ & 3.80 & $3.75^{\mathrm{ab}}$ & $3.76^{\mathrm{bc}}$ & $3.58^{\mathrm{b}}$ & 1.00 & 1.04 & $14.40^{\mathrm{b}}$ & $14.43^{\mathrm{b}}$ \\
\hline $\begin{array}{l}\text { Boric acid } 400 \mathrm{ppm}+\mathrm{GA}_{3} \\
40 \mathrm{ppm}+\text { yeast } 2 \%\end{array}$ & 3.68 & $3.73^{\mathrm{ab}}$ & $3.80^{\mathrm{ab}}$ & $3.75^{\mathrm{ab}}$ & 0.96 & 0.99 & $14.67^{\mathrm{b}}$ & $14.80^{\mathrm{b}}$ \\
\hline
\end{tabular}

Means having the same letters (s) in each column are insignificantly differ at a level of 5\%

significantly affected fruit length The highest fruit length were recorded by spraying $\mathrm{GA}_{3}$ at $40 \mathrm{ppm}$ since it was $3.83,4.0 \mathrm{~cm}$ in both seasons, respectively.

As fruit diameter, results in the same Table cleared that, all treatments had increased fruit diameter as compared with the control in the two seasons.

Spraying $\mathrm{GA}_{3}$ at $40 \mathrm{ppm}$ showed the highest fruit diameter $(3.94 \mathrm{~cm}$ in the first season and $3.86 \mathrm{~cm}$ in the second one).
Fruit shape index (L/D) ratio was not affected significantly by different treatments and there was no clear trend developed for treatments in both seasons of study.

Fruit firmness values in Table (3) proved that all treatments significantly increased fruit firmness in the two seasons when compared with the control. However, spraying boric acid at 400 ppm recorded the highest fruit firmness followed by $\mathrm{GA}_{3}$ at 20 or $40 \mathrm{ppm}$ in the first 
and second seasons, respectively. On the other hand, control treatment recorded the lowest fruit firmness value, during both seasons of such study.

\section{Fruit chemical characteristics}

\section{Total soluble solids\%}

Data presented in Table (4) show that all treatments affected significantly $\mathrm{TSS} \%$ in fruit juice in both seasons as compared with those of the control. The highest TSS\% was obtained by spraying trees with boric acid at $400 \mathrm{ppm}$ in both seasons. Meanwhile, the lowest TSS\% was recorded due to control treatment.

As for total acidity $\%$ of fruit juice it was decreased significantly by different treatments as compared with those the control. The lowest total acidity\% (fruit juice was recorded when trees were spraying with active dry yeast at $1 \%$ in both seasons. While the highest total acidity\% was recorded for the control treatment since it was $2.03 \%$ in both seasons.

Table 4. Effect of foliar spraying with Boric acid, $\mathrm{GA}_{3}$ and active dry yeast on TSS\%, acidity\% and TSS/acid ratio of Canino Apricot trees during 2002 and 2003 seasons.

\begin{tabular}{|c|c|c|c|c|c|c|}
\hline \multirow{2}{*}{ Treatments } & \multicolumn{2}{|c|}{ TSS $\%$} & \multicolumn{2}{|c|}{ Acidity $\%$} & \multicolumn{2}{|c|}{ TSS/acid } \\
\hline & 2002 & 2003 & 2002 & 2003 & 2002 & 2003 \\
\hline Control & $14.43 \mathrm{c}$ & $14.17 \mathrm{c}$ & $2.03 \mathrm{a}$ & $2.03 \mathrm{a}$ & $7.10 \mathrm{~b}$ & $6.98 \mathrm{c}$ \\
\hline Boric acid at $200 \mathrm{ppm}$ & $15.63 \mathrm{a}$ & $15.77 \mathrm{a}$ & $1.89 \mathrm{bcd}$ & $1.91 b c$ & $8.26 \mathrm{a}$ & $8.24 \mathrm{a}$ \\
\hline Boric acid at $400 \mathrm{ppm}$ & $16.03 \mathrm{a}$ & $16.00 \mathrm{a}$ & $1.89 \mathrm{bcd}$ & $1.92 \mathrm{bc}$ & $8.45 \mathrm{a}$ & $8.30 \mathrm{a}$ \\
\hline $\mathrm{GA}_{3}$ at $20 \mathrm{ppm}$ & $14.90 \mathrm{~b}$ & $14.90 \mathrm{~b}$ & $1.94 \mathrm{bc}$ & $1.96 \mathrm{~b}$ & $7.68 \mathrm{ab}$ & $7.59 \mathrm{~b}$ \\
\hline $\mathrm{GA}_{3}$ at $40 \mathrm{ppm}$ & $15.03 b$ & $14.97 \mathrm{~b}$ & $1.95 \mathrm{~b}$ & $1.96 \mathrm{~b}$ & 7.71ab & $7.63 b$ \\
\hline Active dry yeast $1 \%$ & $15.60 \mathrm{a}$ & $15.73 \mathrm{a}$ & $1.86 \mathrm{~d}$ & $1.89 \mathrm{c}$ & $8.37 \mathrm{a}$ & $8.29 \mathrm{a}$ \\
\hline Active dry yeast $2 \%$ & $15.80 \mathrm{a}$ & $15.87 \mathrm{a}$ & $1.92 \mathrm{bcd}$ & $1.90 \mathrm{bc}$ & $8.23 \mathrm{a}$ & $8.34 \mathrm{a}$ \\
\hline $\begin{array}{l}\text { Boric acid } 200 \mathrm{ppm}+\mathrm{GA}_{3} 20 \\
\text { ppm + yeast } 1 \%\end{array}$ & $15.70 \mathrm{a}$ & $15.87 \mathrm{a}$ & $1.88 \mathrm{~cd}$ & $1.91 b c$ & $8.35 \mathrm{a}$ & $8.31 \mathrm{a}$ \\
\hline $\begin{array}{l}\text { Boric acid } 400 \mathrm{ppm}+\mathrm{GA}_{3} 40 \\
\text { ppm + yeast } 2 \%\end{array}$ & $15.80 \mathrm{a}$ & $15.87 \mathrm{a}$ & $1.92 \mathrm{bcd}$ & $1.90 \mathrm{bc}$ & $8.21 \mathrm{a}$ & $8.34 \mathrm{a}$ \\
\hline
\end{tabular}

Means having the same letters (s) in each column are insignificantly differ at a level of 5\% 
Regarding the TSS/acid ratio, it was affected significantly by different treatments. The highest TSS/acid ratio was recorded by spraying boric acid at 400 ppm in the first season, while spraying active dry yeast at $2 \%$ alone or in combination with boric acid at $400 \mathrm{ppm}+\mathrm{GA}_{3}$ at $40 \mathrm{ppm}$ recorded the highest TSS/acid ratio in the second seasons.

\section{DISCUSSION AND CONCLUSIONS}

The general positive effects of applying active dry yeast on growth, nutritional status of trees and productivity could be attributed to its content of different nutrients, higher percentage of proteins, large amount of vitamin B and the natural plant growth hormone mainly cytokinins. In addition, application of active dry yeast was very effective in releasing $\mathrm{CO}_{2}$ which reflected on improving net photosynthesis (Larson et al 1962; FAO, 1971; Ferquson et al 1987 and Idso et al 1995).

The same authors suggested that various positive effects of applying active dry yeast on growth, nutritional status of trees and productivity could be attributed to is content of different nutrients and higher values of vitamins, specially vitamin $B$ which plays a key role in improving growth and controlling the incidence of fungi diseases. In addition, respect active dry yeast was found to improve the nutritional status, yield and fruit physical and chemical properties of Anna apple trees (Mansour, 1998). Moreover, Attala et al 2000 found that applying dry yeast as a biostimulant at the rate $2.48 \mathrm{gm} / \mathrm{L}$ had a beneficial effect on fruit set and fruit drop which had an impact on yield and fruit quality of Le conte pear trees.
The positive effect of $\mathrm{GA}_{3}$ on weight and volume of pear fruit in the same line with those obtained by Higazi et al 1983 .

In additions, Abou Raya et al 2000 found that pear trees sprayed with $10 \mathrm{ppm}$ $\mathrm{GA}_{3}$ at full bloom increased fruit weight and size. In this respect Mostafa et al 2001 found that spraying Le conte pear trees with 50 ppm $\mathrm{GA}_{3}$ increased $\mathrm{N}, \mathrm{P}$ and $\mathrm{K}$ in leaves, increased yield and improved fruit quality as well as (weight, volume, dimensions and TSS.

Moreover, Boron is important in pollen grain germination and pollen tube growth resulting in success full fruit setting (Stanle and Lichtenberg, 1963).

In addition, Yang et al 1999 found that apricot trees fertilization with boron promoted pollen germination increased the fertility percentage and this increased yield. In this respect Eman et al 2002 found that boric acid at $0.1 \%$ spray on Annona flowers increased percentage of fruit set and retention, and significantly increased fruit quality.

From the abovementioned results it could be concluded that Canino Apricot trees grown under sandy soil conditions greatly respond to foliar spraying with boric acid at $400 \mathrm{ppm}$ in combination with $\mathrm{GA}_{3}$ at $40 \mathrm{ppm}+$ active dry yeast at $2 \%$ once at full bloom, where it increased $\mathrm{N}, \mathrm{P}$ and $\mathrm{K} \%$ in the leaves in both seasons, increased yield $(\mathrm{kg} /$ tree $)$, and improved fruit weight and volume.

\section{REFERENCES}

Abou Raya, M.S.; E.A.M.; Mostafa; M.M.M. Abd EL-Migeed and M.M.S. Saleh, (2000). Effect of Paclobutrazol and $\mathrm{GA}_{3}$ foliar sprays on mineral content, yield and quality of "Le Conte" pear trees grown under Rafah conditions Assuit $\boldsymbol{J}$. Agric. Sci., 31 (2): 39 - 48, Egypt. 
Agusti, M.F.; M. Garcia and J.L. Guardiola (1982). Gibberellic acid and fruit set in sweet orange. Scientia Hort., 17: 257-264.

Antognozzi, E. and J.E. Jackson (1975). The effect of orthonil and $\mathrm{GA}_{3}$ on fruiting in the cv. Conference pear. Rivistadella ortofloro frullico Hura Italian. 59 (1) 1 - 9 [C.F. Hort. Abst. 45 : 169).

A.O.A.C. (1985). Official Methods of Analysis. pp. 490-510. Association of Official Analytical Chemists. Washington, D.C.

Attala, Eman S.; Amal M. El-Seginy and G.T Eliwa (2000). Response of Le Conte pear trees to foliar applications with active dry yeast. J. Agric. Sci. Mansoura Univ., 25(12): 8005-8011, Egypt.

Chuntanaparb, N. and G. Cummings, (1981). Seasonal trends in concentration of Nitrogen. Phosphorus, Potassium, Calcium and Magnesium and peach. $\boldsymbol{J}$. Amer. Soc. Hort. Sci., 79: 69336936.

Duncan, D.B. (1955). Multiple range and multiple "f" tests. Biometrics, 11: 1-42.

Eman A.A. Abd El-Moniem, Sanaa Ebeed; A.M. Gomaa and R.G. Stino (2002). Effect of spraying with boric acid, $\mathrm{GA}_{3}$, Amactone, activated yeast and sucrose on Abd El-razik Annona fruit set, and quality. Zagazig J. Agric Res. 29 (5): 1579-1590, Egypt.

Embleton, T.W.; W.W. Jones and C.W. Coggins, Jr. (1973). Aggregate effect of nutrients and Gibberellic acid on "Valencia" orange crop value. J. Amer. Soc. Hort. Sci., 98, (3): 281-285.

F.A.O. (1971). FAO Production Year Book, 446 pp. Food and Agr. Organization of united Nation FAO, Rome, Italy.

Ferguson, J.J.; W.T. Avigne; L.H. Allen and K.E. Koch. (1987). Growth of
$\mathrm{CO}_{2}$ enriched sour orange seedlings treated with gibberellic and cytokinins. Proc. Florida state Hort. Soc. 99: 37-39.

Hegab, M.Y.; F.F. Ahmed and A.H. Ali (1997). Influence of spraying active dry yeast on growth and productivity of Valencia orange trees (Citrus sinensis). Proc. Of the $1^{\text {st }}$ Sci. Conf. of Agric Sci. Fac. Agric., Asssiut Univ. Vol. 1: 73-85, Egypt.

Higazi, A.M.; M.H. El-Hagah; S.Z. ELNaggar and A.A. Kassem (1983) Physico-chemical characters of Le-Conte pear fruits in relation to gibberellic acid effects. Minufiya, J. Agric. Res. 7: 281292, Egypt.

Idso S.B.; K.E. Idos and K.K. Hoober (1995). Effect of atmospheric $\mathrm{CO}_{2}$ enrichment of foliarmethanol application on net photosyne- thesis of sour orange trees (Citrus aurantium) leaves. Amer. J. Botany 82 (1) : 26 - 30.

Larson, P.; A. Herbo; S. Klongson and T. Ashein (1962). On the biogenesis of some compounds in Acetobacter xyliam. Physiol. Plant. 15 : 552 - 565.

Mansour, A.E.A. (1998). Response for Anna apple to some biofertilizers. Egypt. J. Hort. 25 (2): 241-251.

Ministry of Agric. A.R.E. (2003). Acreage and total production of Agric. Crops in A.R.E. Bull. Agric. Econ. and Statistics (In Arabic), p. 298.

Mostafa, E.A.M.; M.M.S. Saleh and M.M.M. Abd-El-Migeed (2001). Improving Le Conte pear trees productivity by spraying $\mathrm{GA}_{3}$ and sucrose. Arab Univ. J. Agric. Sci. Cairo, 9, (1): 373 - 385.

Nyomova, A.M.S. and P.H. Brown (1997). Fall foliar applied boron increases tissue boron concentration and nut set almond. J. Amer. Soc. Hort. Sci. 122 : 405 - 410 . 
Stanle, R.G. and E.A. Lichtenberg (1963). The effect of various boron compounds on in vitro germination of pollen.

Physiol. Plant. 16 : 337-346.

Wertheim, S.J.; F. Nijssee and M.L. Joossee (1973). Attention for gibberellin spraying. Fruitteelt, 63 (16): 413. (C.F. Hort. Abst. 43: 7461).

Wilde, S.A.; R.B. Corey; J.G. Lyer and G.K. Viogt (1985). Soil and Plant Analysis for Tree Culture $3^{\text {rd }}$ Ed. pp. 93-116. Oxford, IBH Publishing Co, New Delhi.
Yang-Xiaoling; Bao-Shidan; Yang-XL and Bao-sd. (1999). Effect of boron fertilizer on flower and fruit drop of apricots. Pedosphere 1999: 9(4): 363368.

Yogaratnam, N. and D.S. Johnson (1982). The application of foliar sprays containing nitrogen, magnesium, zinc and boron to Apple trees. 11. Effect on the mineral composition and quality of the fruit. J. Hort. Sci. 57: 159-164.

بحلة اتحاد الجامعات العربية للدراسات والبحوث الزراعية، جامعة عين شمس، القاهرة ، 13(2)، 471-480، 2005

تحسين انتاجية أشجار المشمش صنف كانينو بالرش بالبورون والجبرالين

والخميرة الجافة النشطة

[30]

$$
\begin{aligned}
& \text { حسن سيد أحمد حسن } 1 \text { - عصام أحمد محمد مصطفى1 } 1 \text { - درية محمد أحمد } 1 \\
& \text { 1- قسم بحوث الفاكهة - المركز القومى للبحوث - شارع البحوث - الدقى - القاهرة - مصر }
\end{aligned}
$$

و الخميرة الجافة النشطة قد أدى إلى تحسين

محتوى الورقة من العناصر و المحصول

وجودة الثمار وذللك بالمقارنة بعدم الرش. منورئ

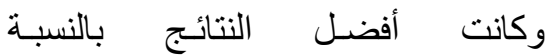

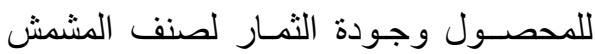

كانينو هـى الرش بمخاليط مـن حض فض

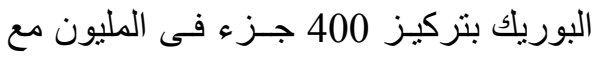

حمض الجبريليك بثركيز 40 جزء فئى فئرئ

المليون مع الخمبر الجافة النشطة بتركيز

$$
\text { 2 فى مرحلة الإز هار الكامل. }
$$

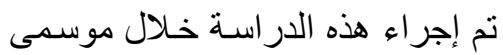

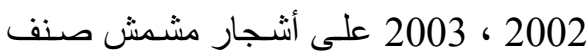

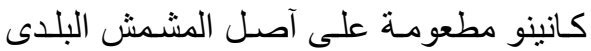

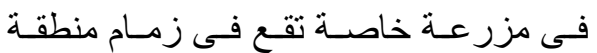

الخطاطبة - محافظة المنوفية.

وفيها تم رش الأشجار فى مرحلة الأزهار

الكامل بالبورون وحمض الجبريليك وكذلك

الخميرة الجافة النشطة بتركيزات مختلفة

منفردة أو فى مخاليط ولقد أظهرت النتائج

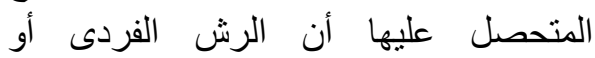

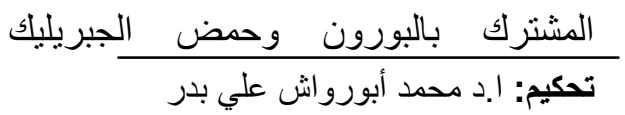

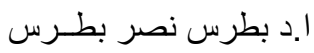

